\title{
Use of Fishing Resources by Women in the Mamanguape River Estuary, Paraíba state, Brazil
}

\author{
MICHELLE S.P. ROCHA ${ }^{1}$, IDALINA M.F.L. SANTIAGO ${ }^{2}$, CREUZA S. CORTEZ ${ }^{1}$, \\ PRISCILA M. TRINDADE ${ }^{3}$ and JOSÉ S. MOURÃ ${ }^{3}$ \\ ${ }^{1}$ Programa Regional de Pós-Graduação em Desenvolvimento e Meio Ambiente, Universidade Federal da Paraíba, \\ Campus Universitário I, CCEN, Cidade Universitária, 58051-970 João Pessoa, PB, Brasil \\ ${ }^{2}$ Departamento de Serviço Social, Universidade Estadual da Paraíba, \\ Rua Antônio Guedes de Andrade, 190, Catolé, 58104-410 Campina Grande, PB, Brasil \\ ${ }^{3}$ Departamento de Biologia, Universidade Estadual da Paraíba, Av. das Baraúnas, 351, \\ Campus Universitário, Bodocongó, 58109-753 Campina Grande, PB, Brasil
}

Manuscript received on January 10, 2011; accepted for publication on March 28, 2012

\begin{abstract}
We evaluated the appropriation and use of fishing resources by women residing near the Mamanguape River Estuary (MRE), Paraíba state, Brazil. Were used combinations of qualitative (interviews and direct observations) and quantitative methods (use value and corrected principal use concordance). Thirty women were interviewed and reported the use of 41 species ( 30 fish, 8 crustaceans, and 3 mollusks), mainly for local consumption and sale. The species with the highest use value were Genidens genidens (0.7), Callinectes exasperatus (0.73) and Anomalocardia brasiliana (0.46). The diversity of resources exploited demonstrates the importance of the mangrove ecosystem to MRE families, and the data gathered can serve as a basis for formulating public policies to promote the equal participation of women in fishing and environmental conservation.
\end{abstract}

Key words: fisher, fishing resources, mangrove, Mamanguape River Estuary.

\section{INTRODUCTION}

Mangrove-estuary complexes are transition areas between freshwater and marine habitats. They occur along the coasts of tropical and subtropical regions and their faunas and floras create intricate food webs essential for maintaining coastal ecosystems (Schaeffer-Novelli 1995). Mangroves are also sources of various natural resources such as lumber, dyes, fishes, crustaceans and mollusks that are essential to the subsistence of local human communities (Alves and Nishida 2003).

Correspondence to: José da Silva Mourão

E-mail: tramataia@gmail.com
An important element that defines the survival of mangrove fishing communities is the family unit, in which all members actively participate in fishing activities to guarantee their survival and extra income (Magalhães et al. 2007). Women living in coastal communities participate in income-generating activities. Their productive organization is directly linked to the use and management of natural marine resources and exhibits strong interactions between productive processes and environmental dynamics. Therefore, understanding the dynamics of this environment, how it is managed by women is one of the keys to 
determining the their degree of influence in fishing communities and to enlist them in the sustainable management of mangrove ecosystems.

Even though women are largely responsible for the regional food production in the Mamanguape River Estuary (MRE; Paraíba state, Brazil) few studies have focused on their participation in the fishing economy of the MRE. The women who live in this estuary have established intimate relationships with the mangrove ecosystem, obtaining resources necessary for the survival of their families and carrying out essential functions in local fishing practices. The present study evaluated the use of MRE fishing resources by fisherwomen and examined the importance of these resources to their livelihood. This information can contribute to future management plans and practices designed to guarantee the sustainable use of species in this region.

\section{STUDY AREA}

The Mamanguape River Estuary is located on the northern coast of Paraíba state, Brazil (6 $6^{\circ} 43^{\prime} 02^{\prime}$ ' to $6^{\circ} 51^{\prime} 54^{\prime \prime} \mathrm{S}$ and $35^{\circ} 01^{\prime} 46^{\prime \prime}$ to $34^{\circ} 54^{\prime} 04^{\prime \prime} \mathrm{W}$; Fig. 1), extends $25 \mathrm{~km}$ from east to west and is $5 \mathrm{~km}$ wide at its mouth. It comprises an area of 16,400 ha, making up part of the Barra de Mamanguape Environmental Protection Area (EPA) created in 1993 to protect coastal ecosystems and West Indian manatees (Trichechus manatus manatus Linnaeus, 1758) (Mourão and Nordi 2002).

The estuarine portion of the EPA includes a vast extension of mangrove swamp covering approximately 6,000 ha, and is one of the most wellpreserved areas in Paraíba state, despite logging for local consumption, the presence of sugarcane plantations, and the large-scale commercial shrimp
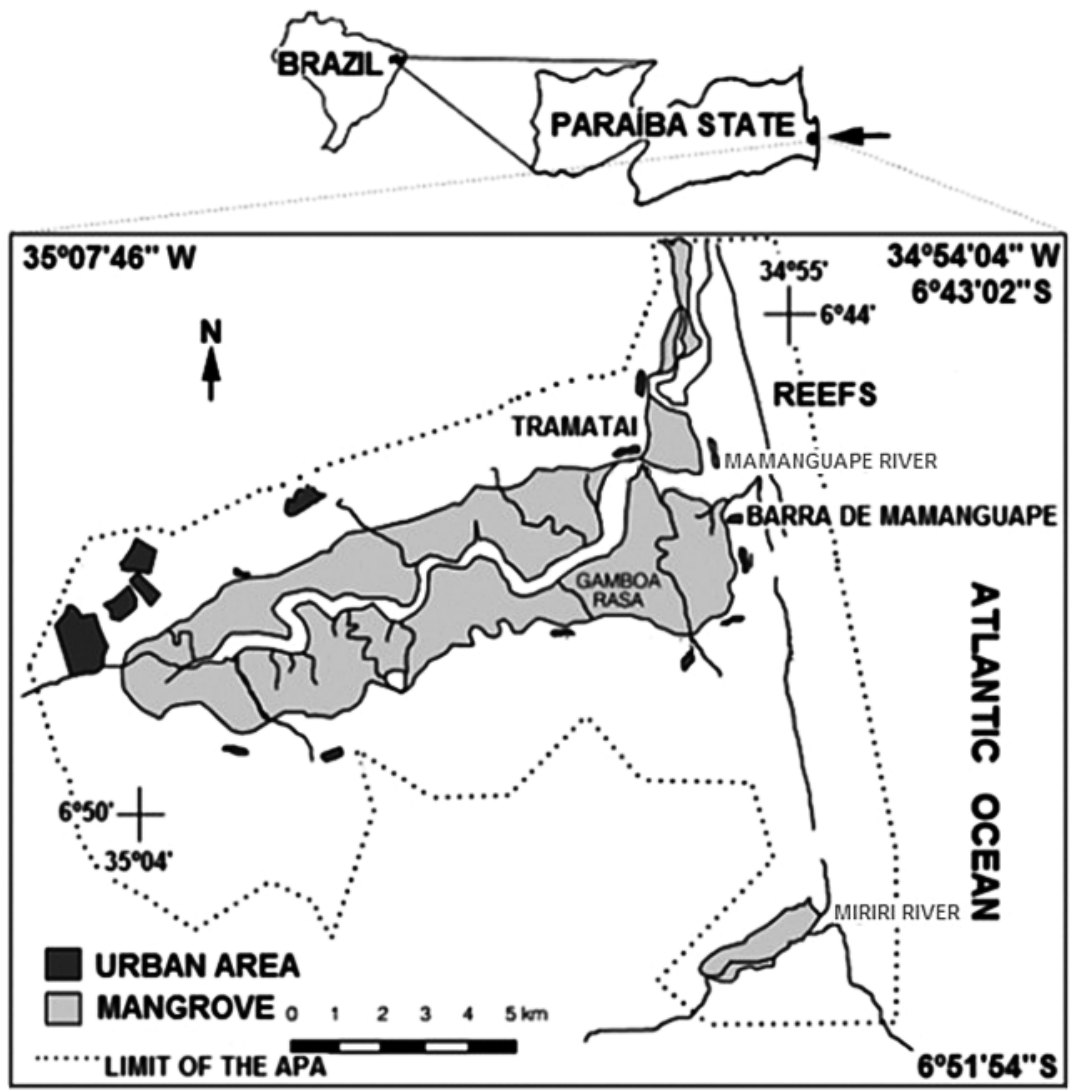

Figure 1 - Estuary of the River Mamanguape. Adapted from: Paludo and Klonowski 1999. 
farming (Alves and Nishida 2003). The flora of the Mamanguape River mangrove swamp is typified by the presence of Rhizophora mangle (red mangrove), Avicennia germinans, A. schaueriana (black mangrove), Laguncularia racemosa (white mangrove), and Conocarpus erectus (button mangrove). The fauna includes fishes, crustaceans and mollusks that constitute the principal subsistence resources of the river-dwelling human communities.

The present study focused on women living in the communities of Aritingui, Barra de Mamanguape, Taberada, Tavares and Tramataia, all located along the banks of the Mamanguape River Estuary. These women take part in fishing activities and harvest mollusks and crustaceans. There are relatively few employment opportunities in the immediate area, limited to manual labor on sugarcane plantations, shrimp farms and tourism. The inhabitants of Aritingui, Taberaba and Tavares, however, are not totally dependent on the mangrove ecosystem because of the sugarcane factories at Miriri and Japungu that can absorb a large part of the workforce; there is also shrimp farming in the region that employs inhabitants of these communities during the harvest season. Additionally, communities members care for small agriculture plots that, together with fishing, provide the principal means of subsistence for their families. Dependence on mangrove resources is greater in Barra de Mamanguape and Tramataia where traditional fishing practices are the principal means of subsistence. Tourism (even on the small current scale) has more recently contributed to improve living conditions in these communities.

\section{METHODS}

Field work was carried out between October 2008 and August 2009, during which monthly or bi-weekly visits lasting from three to seven days each were made to the communities. Information about local fishing was gathered through open and semi-structured interviews, as well as from direct observation by non-participating observers
(Bernard 1994, Viertler 2002). The interviewees were identified using the snowball method (Bailey 1994), in which the women themselves indicated other members of the community as key informants and with whom we subsequently established a closer relationship during the course of the research.

Sampling was intentionally non-random (Almeida and Albuquerque 2002) and the interviewees were all women involved in fishing activities. A total of thirty women were interviewed (Aritingui $=3$; Barra de Mamanguape $=3$; Taberaba $=3$; Tavares $=9$; Tramataia $=12$ ) and chosen based on the following criteria: 1) fishing experience equal to or longer than 10 years; 2) fishing regularly 3 or more days per week; 3) women who performed other activities closely related to fishing (sport fishing guides, collecting natural bait, etc.); and 4) former fisher with 10 or more years of fishing experience. In order to protect intellectual property rights, we followed an informal research protocol in which we briefly explained the nature of the research and specific objectives to each interviewee before initiating the survey (Silvano and Begossi 2005).

Data were analyzed by interpreting the conversations with the interviewees (Mourão and Nordi 2002). The method was based on the union of diverse individual competences model (Hays 1976), which consists of considering all information supplied by all interviewees, without any exclusion.

The vernacular names of the animals were recorded as spoken by interviewees, and their scientific names were subsequently determined from the taxonomic literature (e.g., Figueiredo and Menezes 1980a, b, 1985, Mourão and Nordi 2002, Nishida et al. 2004, 2006, Rocha et al. 2008). A list was prepared of all species cited, as well as of their uses. The animals were grouped into four categories of use (Silvano 2004): commercialization (resources destined for sale); local consumption (resources used only for eating due to their lack of significant commercial value); medicinal (resources used for the treatment of diseases); and fishing bait. 
The use value (adapted from Phillips et al. 1994) was calculated for each species recorded; this is a quantitative method used to determine the relative importance of local species: $\mathrm{UV}=\mathrm{U} / \mathrm{n}$, where $U=$ number of times a species is cited; $n=$ number of interviewees.

Additionally, the corrected principal use concordance (CPUc) index was calculated for each species. This index calculates the relative importance of the principal use of a given species weighted against its other common uses. These calculations were based on the work of Friedman et al. (1986) as modified by Amorozo and Gély (1988). However, unlike these studies, we considered species that were cited only once, as the correction factor (CF) allows for standardization of the results:

$\mathrm{CPU}=\frac{\mathrm{PU} \times 100}{\mathrm{E}} \quad \mathrm{CF}=\frac{\mathrm{E}}{\mathrm{EM}} \quad \mathrm{CPUc}=\mathrm{CPU} \times \mathrm{CF}$

Where: $\mathrm{PU}=$ number of interviewees who cited the principal use(s) of the species; $\mathrm{E}=$ number of interviewees who cited the species (number of citations per species); $\mathrm{EM}=$ number of interviewees who cited the most species.

\section{RESULTS AND DISCUSSION}

\section{FISHING RESOURCES IN MRE}

The fisher in the MRE used a total of 41 different species: 30 fishes, 8 crustaceans and 3 mollusks (Table I), although the exact numbers of fishes, crustaceans and mollusks used differed among communities. The communities of Tramataia and Barra de Mamanguape used the highest numbers of fishes (17 and 12 species respectively). The community of Tramataia harvested the most crustaceans (6 species), and cited a high number of uses for these ( $n=33)$, with "siri" crabs of the family Portunidae being the most heavily exploited ( $n=30$ citations). The harvesting of mollusks was only noted at Barra de Mamanguape $(n=3$ citations), Tavares ( $\mathrm{n}=2$ citations) and Tramataia
( $n=21$ citations), with no reports among the fisher from Aritingui or Taberaba (Table I).

According to interviewees, two factors contribute to the harvesting disparities between these communities: the first is related to the location in relation to the mouth of the Mamanguape River (where the local fisher have access to different habitats and more species of fish); the second is related to the dependence and exclusive dedication of the women of Barra de Mamanguape and Tramataia on fishing (women from the other communities also farm as an auxiliary means of subsistence).

The fisher exploit a high diversity of natural resources in the Mamanguape River estuarymangrove complex. This corroborates the findings from different authors who showed the importance of mangrove areas to the economies of riverside communities and noted the wide spectrum of resources harvested by fisher in these areas (Dias et al. 2007, Lambeth 1999, Paludo and Klonowski 1999 , Rocha et al. 2008, Rönnbäck 1999). Women in the MRE region use several species as a resource base; it is therefore important to ensure that the stocks of these species remain viable to guarantee the economic survival of the many families who depend on them.

The use value (UV) of the species cited varied from 0.03 to 0.73 (Table I). The UV of fish species varied from 0.03 to 0.70 , with "cambueiro" catfish (Genidens genidens - Ariidae) having the highest number of citations $(\mathrm{n}=21 ; \mathrm{UV}=0.7)$, followed by "tainha" (Mugil curema - Mugilidae) and "camurim" (Centropomus sp. - Centropomidae), with 19 and 15 citations respectively. The use values recorded for the crustaceans varied from 0.03 to 0.73 (Callinectes exasperatus (Portunidae) being the species with the highest use value). Of the species of mollusks cited, the clam Anomalocardia brasiliana (Veneridae) had the highest UV ( $\mathrm{n}=14$ citations; UV=0.46). G. genidens, M. curema, Centropomus sp and C. exasperatus were cited by members of all communities studied.

The harvesting of certain species was often observed to be dependent on the location of a 
given community. Bathygobius soporator, for example, was cited as being caught by fisher in the communities located more to the interior of the MRE (Aritingui, Taberaba and Tavares), while A. brasiliana and Opistonema oglinum were only cited by interviewees from Barra de Mamanguape and Tramataia, communities close to the mouth of the Mamanguape River. These finding demonstrate that harvesting patterns for certain species are determined by the distributions and natural habitats of those animals, local species diversity, and/or capture methods used for the resource in question.

As happened with the fisher of the MRE, other studies observed the exploitation of particular species. Dias et al. (2007) reported that the main taxa exploited in the Ponta do Tubarão Reserve (RDSPT - RN) included Gerres sp., Eucinostomus sp., Mugil sp., Lutjanus sp and Anomalocardia brasiliana. According to Cardoso (2007) and Magalhães et al.
(2007), fishing in the mangrove areas of Vila de Guarajubal (PA) and in the Caete estuary (PA) is mostly for crabs, especially Ucides cordatus.

Although previous studies of women harvesting marine resources indicated that they almost exclusively gathered invertebrates such as mollusks and crustaceans, this picture is apparently changing and many women are migrating into areas of fishing that have traditionally been associated to men, such as fishing at sea (Fadigas et al. 2008, Kronen 2002, Pisua and Leonardo 1998). The numbers of fish species found to be harvested $(n=30)$ by the fisherwomen in this study clearly demonstrates the importance of women in the local fishing economy.

As traditional fishing activities undertaken by coastal and riverside communities in mangrove areas have great socioeconomic and cultural importance, the rigorous maintenance of this ecosystem will be required to guarantee the survival of these families.

TABLE I

Use values and corrected principal use concordance of the fishing resources harvested by women in the Mamanguape River Estuary, Paraíba state, Brazil.

\begin{tabular}{|c|c|c|c|c|c|c|c|c|c|c|c|}
\hline \multirow{2}{*}{ Taxon / Family / Species / Local name } & \multicolumn{5}{|c|}{$\begin{array}{l}\text { Number of citations per } \\
\text { community }\end{array}$} & \multirow{2}{*}{$\begin{array}{c}\text { Use } \\
\text { value }\end{array}$} & \multirow{2}{*}{ Uses } & \multirow{2}{*}{ PU } & \multirow{2}{*}{$\begin{array}{c}\text { PUC } \\
(\%)\end{array}$} & \multirow{2}{*}{$\mathrm{CF}$} & \multirow{2}{*}{ PUCc } \\
\hline & $\mathrm{AR}$ & $\mathrm{BM}$ & TB & TV & TM & & & & & & \\
\hline \multicolumn{12}{|l|}{ CHONDRICHTHYES } \\
\hline $\begin{array}{l}\text { Myliobatidae / Myliobates narinari / } \\
\text { "Arraia Pintada" }\end{array}$ & - & - & - & - & 2 & 0.06 & $\mathrm{LC}, \mathrm{S}, \mathrm{MU}$ & $\mathrm{LC}, \mathrm{S}, \mathrm{MU}$ & 50 & 0.09 & 4.5 \\
\hline \multicolumn{12}{|l|}{ OSTEICHTHYES } \\
\hline $\begin{array}{l}\text { Ariidae / Genidens genidens / "Bagre } \\
\text { cambueiro" }\end{array}$ & 3 & 2 & 3 & 3 & 10 & 0.7 & $\mathrm{LC}, \mathrm{S}, \mathrm{B}$ & $\mathrm{LC}$ & 100 & 1 & 100 \\
\hline Carangidae / Trachinotus sp. / "Pampo" & - & - & - & - & 1 & 0.03 & LC,S & $\mathrm{LC}, \mathrm{S}$ & 100 & 0.04 & 4 \\
\hline \multicolumn{12}{|l|}{ Clupeidae } \\
\hline Opisthonema oglinum/ "Sardinha azul" & - & 2 & - & - & 6 & 0.26 & LC,S & $\mathrm{LC}$ & 100 & 0.38 & 38 \\
\hline Sardinella brasiliensis/ "Sardinha fofi" & - & - & - & 1 & 1 & 0.06 & $\mathrm{LC}, \mathrm{S}$ & $\mathrm{LC}$ & 100 & 0.09 & 9 \\
\hline $\begin{array}{l}\text { Centropomidae / Centropomus sp. / } \\
\text { "Camurim" }\end{array}$ & 3 & 2 & 2 & 3 & 5 & 0.5 & $\mathrm{LC}, \mathrm{S}, \mathrm{B}$ & $\mathrm{LC}$ & 100 & 0.71 & 71 \\
\hline $\begin{array}{l}\text { Engraulidae / Lycengraulis grossidens / } \\
\text { "Sardinha arenca" }\end{array}$ & - & - & - & - & 1 & 0.03 & $\mathrm{LC}$ & $\mathrm{LC}$ & 100 & 0.04 & 4 \\
\hline $\begin{array}{l}\text { Ephippidae / Chaetodipterus faber / } \\
\text { "Paru" }\end{array}$ & - & - & - & - & 1 & 0.03 & LC,S & LC,S & 100 & 0.04 & 4 \\
\hline
\end{tabular}


TABLE I (continuation)

\begin{tabular}{|c|c|c|c|c|c|c|c|c|c|c|c|}
\hline \multirow{2}{*}{ Taxon / Family / Species / Local name } & \multicolumn{5}{|c|}{$\begin{array}{l}\text { Number of citations per } \\
\text { community }\end{array}$} & \multirow{2}{*}{$\begin{array}{c}\text { Use } \\
\text { value }\end{array}$} & \multirow{2}{*}{ Uses } & \multirow{2}{*}{$\mathrm{PU}$} & \multirow{2}{*}{$\begin{array}{l}\text { PUC } \\
(\%)\end{array}$} & \multirow{2}{*}{$\mathrm{CF}$} & \multirow{2}{*}{$\mathrm{PUCc}$} \\
\hline & AR & $\mathrm{BM}$ & TB & TV & $\mathrm{TM}$ & & & & & & \\
\hline Erithrinidae / Holopias sp. / "Traira" & - & - & 1 & - & - & 0.03 & $\mathrm{LC}$ & $\mathrm{LC}$ & 100 & 0.04 & 4 \\
\hline \multicolumn{12}{|l|}{ Gerreidae } \\
\hline Diapterus olisthostomus /"Carapeba" & 3 & 1 & 2 & - & 7 & 0.43 & $\mathrm{LC}, \mathrm{S}, \mathrm{B}$ & $\mathrm{LC}, \mathrm{S}$ & 100 & 0.61 & 61 \\
\hline Eucinostomus argentius / "Carapicu" & - & - & - & - & 2 & 0.06 & LC,S,B & LC,S,B & 100 & 0.09 & 9 \\
\hline \multicolumn{12}{|l|}{ Gobiidae } \\
\hline Bathygobius soporator / "Amore" & 3 & - & 3 & 4 & - & 0.3 & LC,S & $\mathrm{LC}$ & 100 & 0.47 & 47 \\
\hline Gobionellus sp. / "Taicica" & - & - & - & 2 & - & 0.06 & $\mathrm{~B}$ & $\mathrm{~B}$ & 100 & 0.09 & 9 \\
\hline \multicolumn{12}{|l|}{ Haemulidae } \\
\hline $\begin{array}{l}\text { Pomodasys corvinaeformis / "Coro } \\
\text { branco" }\end{array}$ & - & 1 & - & - & - & 0.03 & $\mathrm{LC}, \mathrm{S}$ & $\mathrm{LC}, \mathrm{S}$ & 100 & 0.04 & 4 \\
\hline Haemulon steindachneri / "Pirambu" & - & 1 & - & - & - & 0.03 & $\mathrm{LC}, \mathrm{S}$ & $\mathrm{LC}, \mathrm{S}$ & 100 & 0.04 & 4 \\
\hline \multicolumn{12}{|l|}{ Lutjanidae } \\
\hline Lutjanus apodus / "Dentão" & - & 1 & - & - & - & 0.03 & $\mathrm{LC}, \mathrm{S}$ & $\mathrm{LC}, \mathrm{S}$ & 100 & 0.04 & 4 \\
\hline Lutjanus jocu / "Vermelha" & - & - & - & - & 1 & 0.03 & $\mathrm{LC}, \mathrm{S}$ & $\mathrm{LC}, \mathrm{S}$ & 100 & 0.04 & 4 \\
\hline $\begin{array}{l}\text { Megalopidae / Megalops atlanticus / } \\
\text { "Camurupim" }\end{array}$ & - & - & - & - & 1 & 0.03 & MU & MU & 100 & 0.04 & 4 \\
\hline \multicolumn{12}{|l|}{ Mugilidae } \\
\hline Mugil liza / "Curimã" & - & - & 1 & - & - & 0.03 & $\mathrm{LC}$ & $\mathrm{LC}$ & 100 & 0.04 & 4 \\
\hline Mugil curema / "Tainha" & 3 & 2 & 2 & 5 & 7 & 0.63 & $\mathrm{LC}, \mathrm{S}, \mathrm{B}$ & $\mathrm{LC}$ & 100 & 0.9 & 90 \\
\hline $\begin{array}{l}\text { Polynemidae / Polydactylus virginicus } \\
\text { / "Barbudo" }\end{array}$ & - & 1 & - & - & - & 0.03 & LC,S & $\mathrm{LC}, \mathrm{S}$ & 100 & 0.04 & 4 \\
\hline $\begin{array}{l}\text { Pomacentridae / Abudedfduf saxantii } \\
\text { / "Cara" }\end{array}$ & - & - & 1 & - & - & 0.03 & $\mathrm{LC}$ & $\mathrm{LC}$ & 100 & 0.04 & 4 \\
\hline \multicolumn{12}{|l|}{ Sciaenidae } \\
\hline Stellifer sp. / "Cabecudo" & - & 1 & - & - & - & 0.03 & $\mathrm{LC}$ & $\mathrm{LC}$ & 100 & 0.04 & 4 \\
\hline Cynoscion sp. / "Pescada" & - & 1 & - & 2 & 2 & 0.16 & $\mathrm{LC}, \mathrm{S}$ & $\mathrm{LC}$ & 100 & 0.23 & 23 \\
\hline $\begin{array}{l}\text { Synbranchidae / Synbranchus } \\
\text { marmoratus / "Mucum" }\end{array}$ & - & - & - & 1 & - & 0.03 & $\mathrm{LC}$ & $\mathrm{LC}$ & 100 & 0.04 & 4 \\
\hline $\begin{array}{l}\text { Syngnathidae / Hippocampus reidi /" } \\
\text { Cavalo-marinho" }\end{array}$ & - & - & - & - & 1 & 0.03 & MU & MU & 100 & 0.04 & 4 \\
\hline $\begin{array}{l}\text { Tetraodontidae / Colomesus psittacus / } \\
\text { "Baiacu camisa de meia" }\end{array}$ & - & - & - & - & 1 & 0.03 & $\mathrm{LC}, \mathrm{S}, \mathrm{B}$ & $\mathrm{LC}, \mathrm{S}, \mathrm{B}$ & 100 & 0.04 & 4 \\
\hline N.I./"Corongo" & - & - & - & - & 2 & 0.06 & $\mathrm{LC}, \mathrm{S}, \mathrm{B}$ & $\mathrm{LC}, \mathrm{S}$ & 100 & 0.09 & 9 \\
\hline N.I./"Bicuda" & - & 1 & - & - & - & 0.03 & $\mathrm{LC}, \mathrm{S}$ & $\mathrm{LC}, \mathrm{S}$ & 100 & 0.04 & 4 \\
\hline N.I./ "Xilapo" & - & - & - & 2 & - & 0.06 & $\mathrm{LC}, \mathrm{S}$ & $\mathrm{LC}$ & 100 & 0.09 & 9 \\
\hline
\end{tabular}


TABLE I (continuation)

\begin{tabular}{|c|c|c|c|c|c|c|c|c|c|c|c|}
\hline \multirow{2}{*}{ Taxon / Family / Species / Local name } & \multicolumn{5}{|c|}{$\begin{array}{l}\text { Number of citations per } \\
\text { community }\end{array}$} & \multirow{2}{*}{$\begin{array}{l}\text { Use } \\
\text { value }\end{array}$} & \multirow{2}{*}{ Uses } & \multirow{2}{*}{ PU } & \multirow{2}{*}{$\begin{array}{l}\text { PUC } \\
(\%)\end{array}$} & \multirow{2}{*}{$\mathrm{CF}$} & \multirow{2}{*}{ PUCc } \\
\hline & $\mathrm{AR}$ & BM & TB & TV & TM & & & & & & \\
\hline \multicolumn{12}{|l|}{ CRUSTACEA } \\
\hline $\begin{array}{l}\text { Gercacinidae / Cardisoma guainhumi / } \\
\text { "Goiamum" }\end{array}$ & 3 & - & - & 2 & 1 & 0.2 & LC,S & LC,S & 83.3 & 0.27 & 22.5 \\
\hline $\begin{array}{l}\text { Grapisiade / Goniops cruentata / } \\
\text { "Aratu de mangue" }\end{array}$ & - & - & - & 4 & 1 & 0.16 & $\mathrm{LC}, \mathrm{S}, \mathrm{B}$ & $\mathrm{LC}, \mathrm{S}, \mathrm{B}$ & 100 & 0.22 & 22 \\
\hline $\begin{array}{l}\text { Ocypodiade / Ucides cordatus / } \\
\text { "Caranguejo sal - C. Uca" }\end{array}$ & 3 & - & 2 & 4 & - & 0.3 & $\mathrm{LC}, \mathrm{S}, \mathrm{B}$ & $\mathrm{LC}$ & 88.8 & 0.41 & 36.4 \\
\hline $\begin{array}{l}\text { Palinuridae / Palinurus argus / } \\
\text { "Lagosta vermelha" }\end{array}$ & - & 1 & - & - & - & 0.03 & LC,S & LC,S & 100 & 0.045 & 4.5 \\
\hline Paneidae / Paneus sp. / "Camarão" & - & - & 3 & 4 & 1 & 0.26 & $\mathrm{LC}, \mathrm{S}, \mathrm{B}$ & $\mathrm{LC}$ & 100 & 0.36 & 36 \\
\hline \multicolumn{12}{|l|}{ Portunidae } \\
\hline Callinectes exasperatus / "Siri acu" & 3 & 1 & 3 & 4 & 11 & 0.73 & $\mathrm{LC}, \mathrm{S}, \mathrm{B}$ & $\mathrm{LC}$ & 81.8 & 0.86 & 70.3 \\
\hline $\begin{array}{l}\text { Callinectes bocourti / " Siri cagão - } \\
\text { S. nema - S. pimenta" }\end{array}$ & 6 & - & 1 & - & 7 & 0.46 & LC,S & $\mathrm{LC}, \mathrm{S}$ & 92.8 & 0.63 & 58.4 \\
\hline Callinectes sp. / "Siri pontinha" & - & - & - & - & 12 & 0.4 & $\mathrm{LC}, \mathrm{S}, \mathrm{B}$ & LC,S & 100 & 0.54 & 54 \\
\hline \multicolumn{12}{|l|}{ MOLLUSCA } \\
\hline $\begin{array}{l}\text { Mytilidae / Mytella guyanensis / } \\
\text { "Sururu" }\end{array}$ & - & - & - & 1 & - & 0.03 & $\mathrm{LC}, \mathrm{S}$ & LC,S & 100 & 0.07 & 7 \\
\hline $\begin{array}{l}\text { Ostreidae / Cassostrea rhizophorae / } \\
\text { "Ostra" }\end{array}$ & - & 1 & - & 1 & 9 & 0.36 & LC,S & $\mathrm{LC}$ & 100 & 0.78 & 78 \\
\hline $\begin{array}{l}\text { Veneridae / Anomalocardia brasiliana } \\
\text { / "Marisco" }\end{array}$ & - & 2 & - & - & 12 & 0.46 & LC,S & $\mathrm{LC}$ & 92.8 & 1 & 92.8 \\
\hline
\end{tabular}

Communities - AR: Aritingui; BM: Barra de Mamanguape; TB: Taberaba; TV: Tavares; TM: Tramataia. Uses - LC: local consumption; S: sale; B: bait; MU: medicinal use. PU: principal uses of species; PUC: principal use concordance; CF: correction factor; PUCc: corrected principal use concordance. N.i.: species/family not identified.

\section{USE OF THE FISHERIES RESOURCES}

The fishery resources harvested by women in the MRE were intended primarily for local consumption, commerce, medicinal and bait uses (Table I). A large part of the catch was destined for local consumption (47\%, Fig. 2), as an important source of protein for families. A third of the catch (33\%) was for both local consumption and commerce. Only a few fishes $(7 \%$ - Fig. 2; Hippocampus reidi, Megalops atlanticus and Myliobates narinari) were used for medicinal purposes such as treatment of asthma.
The highest corrected principal use concordance (CPUc) values were for "cambueiro" catfish (G. genidens - 100\%), "tainha” (M. curema-90\%) and "camurim" (Centropomus sp. - 71\%) (Table I). These species also had the highest use values (UV) and were regarded by the interviewees as the most important species, especially for local consumption.

Approximately $50 \%$ of the crustaceans were destined for local consumption or sale to members of the community, tourists, or restaurants in neighboring cities and $37.5 \%$ were only consumed 


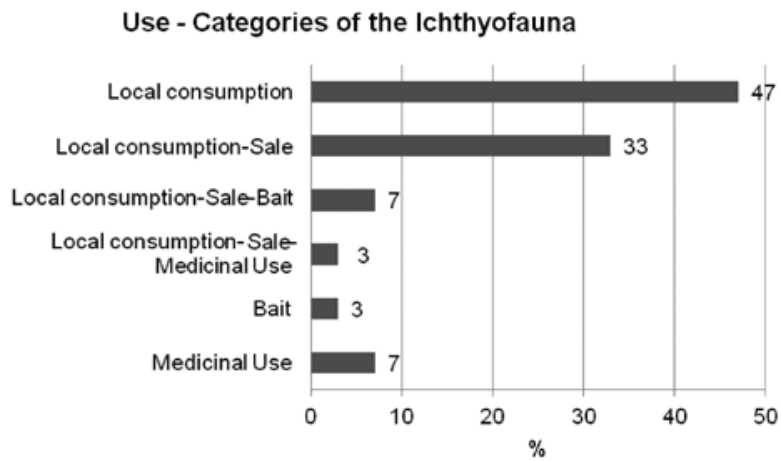

Figure 2 - Use categories of ichthyofauna harvested by women in the Mamanguape River Estuary, Paraíba state, Brazil.

by the families of the harvesters (Fig. 3). Another $12.5 \%$ were destined for home consumption, sale or bait - e.g., mangrove root crabs (Goniopus cruentata) and mud crabs (Callinectes sp.). There was no record of crustaceans being used for medicinal purposes among the interviewees in the present study. $C$. exasperatus showed the highest CPUc (70.3\%), followed by C. bocourti $(58.4 \%)$. Both were consumed locally.

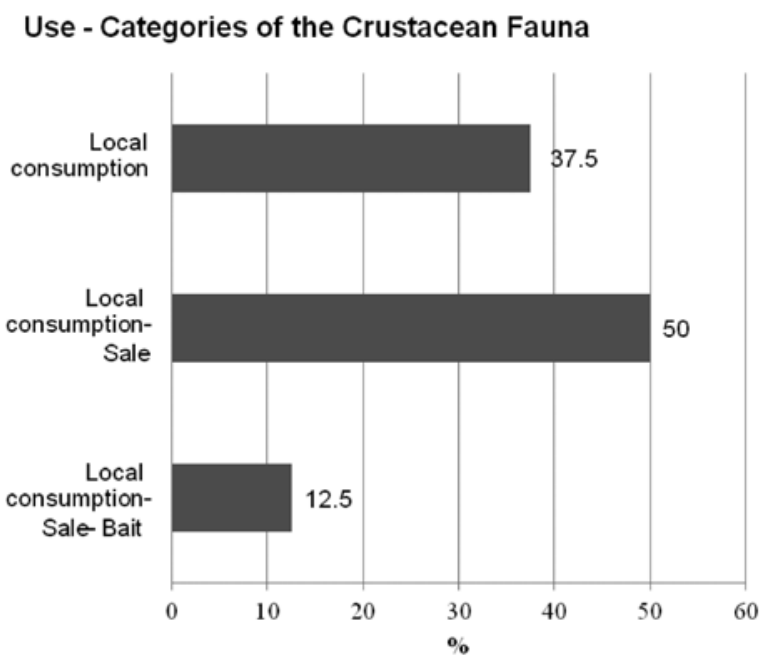

Figure 3 - Use-categories of the crustacean fauna harvested by women in the Mamanguape River Estuary, Paraíba state, Brazil.

Most mollusks collected were mainly used in local consumption (75\%), with A. brasiliana having the highest concordance percentage in relation to its use $(\mathrm{CPUc}=92.8 \%)$. Surplus mollusks were also sold ( $25 \%$ of cases) in the local community and in open markets in neighboring cities.

The importance of fishing resources as income and food for the communities in and around the MRE corroborates studies in other fishing communities in Brazil showing that most of these resources are used for family consumption, commercial purposes, bait, and folk medicine (Alves and Rosa 2007, Silvano 2004).

Many authors have noted that crustaceans represent an important resource for populations living in mangrove areas, and many women traditionally dedicate considerable effort to harvest these resources (Cardoso 2007, Dias et al. 2007, Magalhães et al. 2007, Matthews 2002). Crustaceans are one of the most important groups in the domestic economies of families living near mangrove swamps in Paraíba state (Alves and Nishida 2003).

Despite the general scarcity of studies on mollusk harvesting, investigations have pointed to the importance of shellfish for communities that depend on mangrove resources. Dias et al. (2007) in Rio Grande do Norte state, and Fadigas et al. (2008) in the Goiana and Megaó river estuaries (PB/PE) noted that shellfish are of significant importance as food resources in coastal communities.

Women contribute significantly to fishing activities in various regions of the world (Golder and MacDonald 2002, Matthews 2002, Kronen 2002). These authors pointed out that the contribution of women includes not only subsistence fishing but also small-scale, village-based commercial activities. The diversity of resources harvested by fisher in the MRE, whether for sale or family consumption, demonstrates the importance of the diverse marine-estuary resources of the mangrove to local subsistence economies, making it urgent to formulate management guidelines for these natural resources. Such guidelines should in turn guarantee the persistence of both local biodiversity as and the subsistence communities built around it. 


\section{SOCIOECONOMICS ASPECTS}

The ages of the informants ranged from 18 to 55 years (average 36.5 years) and their fishing experience ranged from 10 to 50 years (mostly 20-30 years; $43.75 \%$ ). Sixty seven percent of women had stable partners $-40 \%$ within stable marital relationships, $27 \%$ in consensual unions. The number of individuals per family ranged from 1 to 8 , with a mode of three individuals. The education level of the respondents was relatively low, $27 \%$ of women being illiterate or $33 \%$ having an incomplete primary education. As noted by Dias et al. (2007), the shellfish collectors of Rio Grande do Norte begin working very early, usually with their mothers, and the socioeconomic positions of these fisher are very precarious.

The large number of adults interviewed in this survey provides a good understanding of the traditional fishing culture, due to the accumulated experience of many years in this profession. These women generally became involved with fishing when they were very young, usually due to their lack of formal education or lack of opportunities in other professions. The low educational level and the few employment opportunities are factors directly related to the high degree of dependence of the fishery resources. Therefore, there is the need for actions aimed at maintaining the ecosystem of the MRE, since many of these women have in fishing the only way to provide for their families. The large numbers of family members observed in some households was often due to the aggregation of children from previous relationships, but may also reflect extended families still sharing the parents' home after marriage. These factors lead to the formation of fishing groups linked by kinship, which can often promote greater fishing success (Diegues 2001).

Women of the MRE divided their time between fishing activities and domestic obligations, and $30 \%$ of them were also involved in agriculture. Traditional fishing is no longer the only economic activity in most coastal communities, and the complementary activities undertaken by women include tourism, commerce, domestic services, and agriculture (Escallier 2004, Hanazaki et al. 1996). Reconciling family and domestic tasks with fishing activities is a permanent problem in the lives of shellfish harvesting communities along the Brazilian coast (Dias et al. 2007, Maneschy 2000).

Approximately $43 \%$ of interviewees had fishing licenses and $20 \%$ were registered as rural workers, for a total of $63 \%$ of women with some kind of legally registered profession and contributing to Social Security, thus ensuring their rights to maternity leave, retirement, and other similar benefits. Family income is always very low and $60 \%$ of the women interviewed were living on incomes below the legal minimum wage (about US\$350.00/month) while the other $40 \%$ earned less than two minimum wages. $72 \%$ of the MRE fisher had alternative sources of income, ranging from pensions $(6 \%)$ or retirement benefits (3\%) and may have received government aid through social programs (e.g., "Bolsa Familia" - $60 \%$ or "PETI" - $3 \%$ ). It should thus be clear that fishing communities are peripheral groups within the country's economic system, and that they are heavily dependent on the natural resources found in the mangrove ecosystem.

\section{CONCLUSIONS}

In spite of recent changes in the economic and environmental conditions, these fishing communities are still greatly dependent on natural marineestuary resources. The diversity of fishing resources harvested by the women interviewed in this study reinforces the importance of mangrove ecosystems in the subsistence of coastal and riverside communities, as well as the crucial roles of these areas for the breeding, reproduction and development of many marine and freshwater species.

Socioeconomic data revealed that the women in these communities fish as the main means of family subsistence, although they can also perform other agricultural activities to supplement 
family resources. The work carried out by these fisherwomen in the MRE is important to the maintenance of their families and for the economic growth of the community, especially in light of their otherwise precarious conditions of education, health, infrastructure and income.

\section{ACKNOWLEDGMENTS}

We thank the fishermen and women of Aritingui, Barra de Mamanguape, Taberaba, Tavares and Tramataia for their hospitality and for the information they provided; and the administration of the Mamanguape River EPA for their logistical support.

\section{RESUMO}

Nós analisamos a apropriação e o uso dos recursos pesqueiros pelas mulheres que moram no Estuário do Rio Mamanguape, Estado da Paraíba, Brasil. Foi usada uma combinação de métodos qualitativos (entrevistas e observações diretas) e quantitativos (valor de uso e concordância de uso principal corrigido). Foram entrevistadas 30 mulheres e registrado o uso de 41 espécies (peixes -30 , crustáceos -08 e moluscos -03 ), principalmente para consumo local e venda. As espécies com maior valor de uso foram Genidens genidens $(0,7)$, Callinectes exasperatus $(0,73)$ e Anomalocardia brasiliana $(0,46)$. A diversidade de recursos explorados demonstra a importância do manguezal para as famílias do ERM, e os dados coletados podem servir de base para a formulação de políticas públicas que promovam a participação igualitária de mulheres na pesca, e na conservação ambiental.

Palavras-chave: pescadoras, recursos pesqueiros, manguezal, Estuário do Rio Mamanguape.

\section{REFERENCES}

Almeida CFC AND AlbuQUerque UP. 2002. Uso e conservação de plantas e animais medicinais no estado de Pernambuco (Nordeste do Brasil): um estudo de caso. Interciência 27: 276-285.

Alves RRN AND NisHidA AK. 2003. Aspectos socioeconômicos e percepção ambiental dos catadores de caranguejouçá, Ucides cordatus cordatus (L. 1763) (Decapoda, Brachyura), no estuário do Rio Mamanguape, Nordeste do Brasil. Interciência 28: 36-43.
ALVES RRN AND ROSA IL. 2007. Zootherapeutic practices among fishing communities in North and Northeast Brazil: A comparison. J Ethnopharm 111: 82-103.

AMOROZO MCM AND GÉLY A. 1988. Uso de plantas medicinais por caboclos do Baixo Amazonas, Barcarena, PA, Brasil. Bol Mus Para Emílio Goeldi Bot 4: 47-131.

BAILEY K. 1994. Methods of Social Research. $4^{\text {th }}$ ed., New York: The Free Press, 588 p.

BERNARD R. 1994. Research methods in anthropology: qualitative and quantitative approaches, Thousand Oaks: Sage Publications, 846 p.

Cardoso DM. 2007. Catadoras de caranguejo e saberes tradicionais na conservação de manguezais da Amazônia brasileira. Rev Estud Fem 15: 485-490.

DiAS TLP, RosA RS AND DAMASCENO LCP. 2007. Aspectos socioeconômicos, percepção ambiental e perspectivas das mulheres marisqueiras da Reserva de Desenvolvimento Sustentável Ponta do Tubarão (Rio Grande do Norte, Brasil). Gaia Sci 1: 25-35.

DiEgues AC. 2001. Ecologia Humana e Planejamento Costeiro. $2^{\text {nd }}$ ed., São Paulo: NUPAUB- USP, 225 p.

ESCALLIER C. 2004. Activités et stratégies de survie dans une communauté de pêcheurs: Le rôle de la femme dans l'économie touristique (Nazaré-Portugal). Multiciência 2: 1-25.

FADIGAS ABM, GARCIA LG AND HERNÁNDEZ MI. 2008. As contribuições das marisqueiras para uma gestão sócioambiental em reservas extrativistas. Rev Estud Fem 8: 1-7.

Figueiredo JL AND MenEzes NA. 1980a. Manual de peixes marinhos do sudeste do Brasil III: Teleostei (2), São Paulo: Mus Zool - USP, 90 p.

FigueIREDo JL AND MENEZES NA. 1980b. Manual de peixes marinhos do sudeste do Brasil IV: Teleostei (3), São Paulo: Mus Zool - USP, 96 p.

Figueiredo JL AND MENEZES NA. 1985. Manual de peixes marinhos do sudeste do Brasil V: Teleostei (4), São Paulo: Mus Zool - USP, 105 p.

FRIEDMAN J, YANIV Z, DAFNI A AND PALEWITCH D. 1986. A preliminary classification of the healing potential of medicinal plants, based on a rational analysis of an ethnopharmacological field survey among Bedouins in the Negev Desert, Israel. J Ethnofarm 16: 275-287.

Golder B AND MACDONALD M. 2002. Population and gender dynamics in coastal conservation in East Africa. SPC Women Fish Inf Bull 11: 10-13.

HANAZAKI N, LEITÃo-FILHO DF AND Begossi A. 1996. Uso de recursos na Mata Atlântica: o caso da ponta da Almada (Ubatuba, Brasil). Interciência 21: 268-276.

HAYS TE. 1976. An Empirical Method for the Identification of Covert Categories in Ethnobiology. Am Ethnol 3: 489-507.

KRONEN M. 2002. Socioeconomic status of fisherwomen. SPC Women Fish Inf Bull 1: 17-22.

LAMBETH L. 1999. An assessment of the role of women within fishing communities in the Republic of Palau, New Zeland: Secrt Pac Comm, $41 \mathrm{p}$.

Magalhães A, Costa RM, Silva R And Pereira LC. 2007. The role of women in the mangrove crab (Ucides cordatus, Ocypodidae) production process in North Brazil (Amazon region, Pará). Ecol Econ 6: 559-565. 
MANESCHY MC. 2000. Da casa ao mar: papéis das mulheres na construção da pesca responsável. Proposta 84: 82-91.

MATTHEWS E. 2002. Integrating women's subsistence fishing into Pacific fisheries conservation programs. SPC Women Fish Inf Bull 1: 13-15.

MOURÃo JS AND NORDI N. 2002. Principais critérios utilizados por pescadores artesanais na taxonomia folk dos peixes do estuário do Rio Mamanguape, Paraíba - Brasil. Interciência 27: 1-7.

NishidA AK, NoRdi N AND AlvES RRN. 2004. Abordagem etnoecológica da coleta de moluscos no litoral paraibano. Trop Oceanogr 32: 53-68.

NishidA AK, NORDI N AND ALVES RRN. 2006. The lunar-tide cycle viewed by crustacean and mollusk gatherers in the State of Paraíba, Northeast Brazil and their influence in collection attitudes. J Ethnobiol Ethnomed 2: 11.

PALudo D AND KLONOWSKI VS. 1999. Barra de Mamanguape - PB: estudo do impacto do uso de madeira de manguezal pela população extrativista e da possibilidade de reflorestamento e manejo dos recursos madeireiros, Série Cadernos da Reserva da Biosfera da mata Atlântica, São Paulo: MAB - UNESCO - MMA 16: 54.

Phillips O, Gentry AH, REYNEl C, Wilkin P AND GALVEZDURAND BC. 1994. Quantitative Ethnobotany and Amazonian Conservation. Conserv Biol 8: 225-248.
PisUa L AND LeONARDO A. 1998. Women can fish too. The role of women in Peru's artisanal fishing sector is often obscured by machismo and bureaucracy. Samudra Rep 1: 33-35.

Rocha MSP, MOURÃo JS, SOUTO WMS, BARBOZA, RRD AND ALVES RRN. 2008. O uso dos recursos pesqueiros no estuário do rio Mamanguape, estado da Paraíba, Brasil. Interciência 33: 1-8.

RöNNBÄCK P. 1999. The ecological basis for economic value of seafood production supported by mangrove ecosystems. Ecol Econ 29: 235-259.

SCHAEFFER-NovelLI Y. 1995. Manguezal: ecossistema entre terra e mar, Caribe: Ecol Res, 64 p.

SILVANO RAM. 2004. Pesca artesanal e etnoictiologia. In: Begossi A (Org), Ecologia de pescadores da Mata Atlântica e da Amazônia, São Paulo: HUCITEC - NAPAUB/USP FAPESP, p.187-222.

SiLvano RAM AND BEGOSSI A. 2005. Local knowledge on a cosmopolitan fish Ethnoecology of Pomatomus saltatrix (Pomatomidae) in Brazil and Australia. Fish Res 71: 43-59.

VIERTLER RB. 2002. Métodos antropológicos como ferramentas para estudos em etnobiologia e entoecologia. In: Amorozo MCM, Ming LC and Silva SMP. Métodos de coleta e análise de dados em etnobiologia, etnoecologia e disciplinas correlatas. Rio Claro: Coord da Área de Ciências Biológicas - UNESP/CNPq, p. 11-29. 